OPEN ACCESS

Edited by:

Lilei Yu,

Wuhan University, China

Reviewed by:

Thorsten Gietzen,

University of Heidelberg, Germany

Hong Jiang,

Renmin Hospital of Wuhan

University, China

*Correspondence:

Xiang Xie

xiangxie999@sina.com

Yitong Ma

myt_xj@sina.com

Specialty section:

This article was submitted to General Cardiovascular Medicine,

a section of the journal

Frontiers in Cardiovascular Medicine

Received: 28 June 2021

Accepted: 27 September 2021

Published: 26 October 2021

Citation:

Yan J, Madina M, Deng C, Yuan Q, Cao S, Xie X and Ma Y (2021) Analysis of 9 Cases of Takotsubo Syndrome and an Analysis of the Clinical Characteristics of Takotsubo Syndrome From a Chinese Population.

Front. Cardiovasc. Med. 8:732193. doi: 10.3389/fcvm.2021.732193

\section{Analysis of 9 Cases of Takotsubo Syndrome and an Analysis of the Clinical Characteristics of Takotsubo Syndrome From a Chinese Population}

\author{
Ju Yan 1,2, Mahesutihan Madina 1,2, Changjiang Deng ${ }^{1,2}$, Qianru Yuan ${ }^{1,2}$, Shixiong Cao ${ }^{1}$, \\ Xiang $\mathrm{Xie}^{1,2 *}$ and Yitong $\mathrm{Ma}^{1,2 *}$ \\ ${ }^{1}$ The First Affiliated Hospital of Xinjiang Medical University, Ürümqi, China, ${ }^{2}$ Department of Cardiology, The First Affiliated \\ Hospital of Xinjiang Medical University, Ürümqi, China
}

Objective: To summarize the clinical features, hematology and imaging features of Takotsubo syndrome.

Methods: The hospitalization data of Takotsubo syndrome patients in the First Affiliated Hospital of Xinjiang Medical University from January 2015 to December 2020 were collected, and their clinical characteristics were summarized. Patient outcomes were clarified through follow-up visits, and relevant objective indicators were statistically analyzed before and after admission. The characteristics of TTS incidence in Chinese population were summarized by searching three (Wanfang, CNKI, China's VIP database) major databases in China (PRISMA).

Results: A total of 9 patients were enrolled, including 6 females (66.7\%). The mean age of onset was 46.4 years old, the median time from onset to treatment was 1 day. The main symptom of 8 cases (88.9\%) was chest pain, 1 case had a main symptom of syncope, and 7 cases (77.8\%) had mood fluctuations or mental stimulation as the main symptom of the disease. Paired $T$-tests were conducted on routine blood, biochemical, coagulation, myocardial markers, inflammatory indicators and objective indicators of ECG before and after admission. The study found that the counts of white blood cells and neutrophils were statistically significant $(P<0.05)$. Prolongation of the QT interval was observed in all 9 patients. After a mean follow-up of $24 \pm 28$ months, no adverse cardiovascular events or recurrence occurred.

Conclusion: Takotsubo syndrome is a group of clinical syndromes with emotional or somatic stimulation and chest pain as the main symptoms, partly accompanied by an increase in white blood cells, neutrophilic granulocyte count, creatine kinase, and troponin and is characterized by a prolonged QT interval and no obvious coronary stenosis. The prognosis is generally good, with few serious complications.

Keywords: Takotsubo syndrome, stress cardiomyopathy, broken heart syndrome, case analysis, clinical characteristics 
Takotsubo syndrome (TTS) is also known as stress cardiomyopathy, apex spherical syndrome, octopus pot cardiomyopathy, broken heart syndrome, stress-induced cardiomyopathy, and Holy Bottle syndrome. Due to the continuous development of society, people's pressure is increasing, which is easy to induce Takotsubo syndrome. The clinical symptoms and electrocardiographic manifestations of this syndrome are similar to those of acute coronary syndrome. The main characteristic of this syndrome is regional abnormal left ventricular wall motion accompanied by abnormal left ventricular dilation during the systolic period. After the removal of the related inducements, the cardiac function of the patient returns to normal, and the prognosis is generally good. By retrospectively collecting the baseline data, clinical data and follow-up of patients with Takotsubo syndrome, we summarized the relevant clinical features of Takotsubo syndrome to facilitate more medical personnel to understand Takotsubo syndrome and to provide clinical guidance, since the current diagnostic method is mainly by a diagnosis by exclusion.

\section{CASE DATA AND METHODS}

\section{Inclusion and Exclusion}

Inclusion criteria were mainly based on the criteria for Takotsubo syndrome published by the Mayo Clinic; the main contents are as follows: (1) transient hypokinesia or abnormal movement in the middle segment of the left ventricle with or without apical involvement. Abnormal regional wall movement exceeds the distribution of single epicardial vessels. Triggers of stress

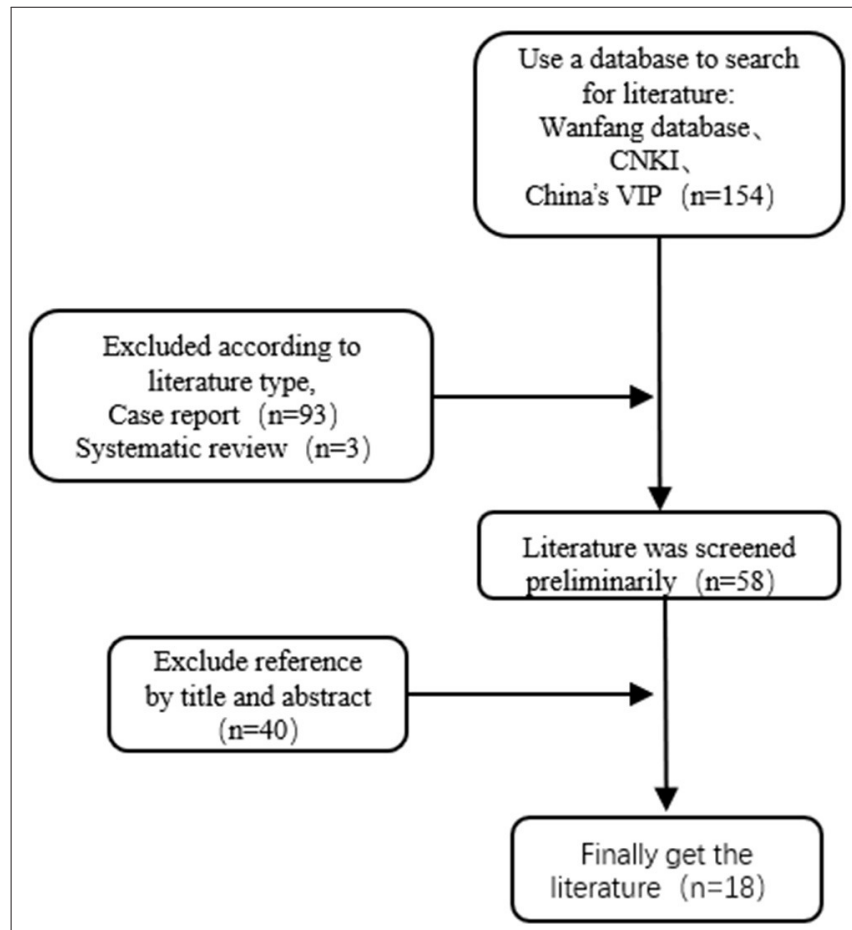

FIGURE 1 | Inclusion of literature process are often present, but not always. (2) No angiographic evidence of obstructive coronary artery disease or acute plaque rupture. (3) New ECG abnormalities (ST-segment elevation and/or Twave inversion) or mild myocardial troponin elevation (1). The exclusion criteria were as follows: (1) patients with a definite diagnosis of CHD by coronary angiography; (2) patients with abnormal left ventricular wall motion consistent with a single coronary artery region; (3) pheochromocytoma and myocarditis; and (4) patients with poor compliance. If the inclusion of a patient was controversial, the patient was reviewed by all members of the TTS team to reach a consensus.

\section{Observation Indicators}

Age of onset, sex, ethnicity, admission time, admission method, initial clinical manifestations (chief complaint, main symptoms, inducement, location, size, nature, duration, aggravating or mitigating factors, concomitant symptoms), previous medical history, admission vital signs, height and weight of all patients were recorded. Serological examination results (routine blood, biochemical, myocardial enzyme, troponin, coagulation set, CRP, PLT, IL-6, etc.), auxiliary examination (ECG, cardiac ultrasound, coronary angiography, myocardial nuclide scan, cervical vascular ultrasound, etc.,) and follow-up to observe whether the patient has recurrence or aggravation were also recorded.

\section{Research Methods}

This study was a retrospective, non-case-control follow-up study. The clinical data of Takotsubo syndrome patients in the First Affiliated Hospital of Xinjiang Medical University from January 2015 to December 2020 were collected, and the descriptive statistical analysis was conducted using Excel and SPSS 21.0. For measurement data, a normal test was carried out first, and the means plus standard deviations was used to describe those data following a normal distribution. Paired T-tests were used for the same patient from admission to discharge. The factors that did not follow a normal distribution are represented by the median (P25, P75), and the comparison between the two groups was performed by the Mann-Whitney test. For the enumeration data, we described the composition of the index by calculating its constituent ratio (\%). A mean follow-up of $24 \pm 28$ months was followed for recurrence or exacerbation.

\section{The Clinical Characteristics of Takotsubo Syndrome in Chinese Population Were Searched Through Three Major Databases in Chinese}

By searching three major databases: Wanfang, CNKI and China's VIP database. The search terms were "stress cardiomyopathy" or "Takotsubo syndrome" or "broken heart syndrome" or "apical spherical syndrome" or "octopus pot cardiomyopathy" or "stressinduced cardiomyopathy" or "Holy Bottle syndrome." Chinese literatures published before April 31, 2021 were selected for reading, and their references were supplemented for reading. Inclusion criteria were consistent with the diagnostic criteria published by the Mayo Clinic. Exclusion criteria patients also 
TABLE 1 | Onset characteristics of Takotsubo syndrome in some Chinese population.

\begin{tabular}{|c|c|c|c|c|c|c|c|c|c|}
\hline References & Cases & Gender & Age & Incentive & Symptoms & ECG & UCG & LVG & Follow up \\
\hline Tan and Luo (2) & 5 & $F(100 \%)$ & $57-76$ & $\mathrm{ES}^{*}: 3$ cases & Chest pain & ST-SE and T-WI & $\begin{array}{l}\text { EF: } 19-34 \% \text {, the apical } \\
\text { movement disappeared } \\
\text { in } 2 \text { cases and } \\
\text { decreased to flat in } 3 \\
\text { cases }\end{array}$ & $\begin{array}{l}\text { Left ventricular } \\
\text { angiography showed } \\
\text { bulbous apex dilatation } \\
\text { with significantly reduced } \\
\text { or absent movement }\end{array}$ & $\begin{array}{l}7-33 \mathrm{~m}, \text { no recurrence } \\
\text { occurred in } 5 \text { patients }\end{array}$ \\
\hline Mo (3) & 27 & $F(66.7)$ & $21-74$ & $\begin{array}{l}\text { ES: } 10 \text { cases, } \\
\text { PS }^{\#}: 17 \text { cases }\end{array}$ & $\begin{array}{l}\text { Chest pain, fainting, } \\
\text { difficulty breathing }\end{array}$ & $\begin{array}{l}\text { ST-SE'a }: 7 \text { cases, } \\
\text { ST-SD }: 20 \text { cases, } \\
\text { T-WI }: 7 \text { cases, }^{\mathrm{C}} \\
\text { QTC-IPd }: 7 \text { cases }\end{array}$ & $\begin{array}{l}\text { EF decreased } \\
\text { significantly, and the } \\
\text { apical and } \\
\text { mid-segment motion } \\
\text { abnormalities of the left } \\
\text { ventricle were found in } \\
7 \text { cases }\end{array}$ & $\begin{array}{l}5 \text { cases of left ventricular } \\
\text { angiography showed that } \\
\text { the apex of the left } \\
\text { ventricle was bulbous }\end{array}$ & $\begin{array}{l}21 \mathrm{~d} \text {, no recurrence } \\
\text { occurred in } 27 \text { patients }\end{array}$ \\
\hline Sun and Xuan (4) & 6 & $F(83.3 \%)$ & $48-72$ & $\begin{array}{l}\text { ES: } 4 \text { cases, PS: } 2 \\
\text { cases }\end{array}$ & $\begin{array}{l}\text { Chest pain, fainting } \\
\text { shortness of breath, } \\
\text { difficulty breathing }\end{array}$ & ST-SE and T-WI & $\begin{array}{l}\text { EF: } 20-35 \% \text {, the apical } \\
\text { movement disappeared } \\
\text { in } 3 \text { cases, and the } \\
\text { movement significantly } \\
\text { weakened to flat in } 3 \\
\text { cases }\end{array}$ & $\begin{array}{l}\text { No coronary angiography } \\
\text { was done }\end{array}$ & $\begin{array}{l}7-11 \text { d, LVEF and apical } \\
\text { wall motion returned to } \\
\text { normal }\end{array}$ \\
\hline Gao et al. (5) & 9 & F (77.8\%) & $42-67$ & $\begin{array}{l}\text { ES: } 3 \text { cases, FS: } 6 \\
\text { cases }\end{array}$ & $\begin{array}{l}\text { Chest pain, difficulty } \\
\text { breathing, fainting }\end{array}$ & $\begin{array}{l}\text { ST-SE: } 2 \text { cases, ST-SD: } \\
6 \text { cases, abnormal Q } \\
\text { wave in } 1 \text { case }\end{array}$ & $\begin{array}{l}\text { EF: } 30-45 \% \text {. Absence } \\
\text { of apical movement } \\
\text { and reduced segmental } \\
\text { movement of } \\
\text { ventricular wall }\end{array}$ & $\begin{array}{l}\text { Coronary angiography } \\
\text { showed no obvious } \\
\text { abnormality }\end{array}$ & $\begin{array}{l}7-14 \text { d, LVEF and } \\
\text { ventricular wall } \\
\text { movement were restored, } \\
\text { and } 2 \text { cases had slight } \\
\text { decrease in the apex }\end{array}$ \\
\hline Liu et al. (6) & 10 & $F(90 \%)$ & $49-83$ & $\begin{array}{l}\text { ES: } 8 \text { cases, FS: } 2 \\
\text { cases }\end{array}$ & Chest pain, fainting & $\begin{array}{l}\text { ST-SE: } 10 \text { patients, } \\
\text { QTC-IP was prolonged }\end{array}$ & $\begin{array}{l}\text { EF: } 46.67 \pm 1.41 \% . \\
\text { Segmental ventricular } \\
\text { wall movement was } \\
\text { abnormal at the apex }\end{array}$ & $\begin{array}{l}9 \text { cases of left ventricular } \\
\text { angiography showed } \\
\text { bulbous apex dilatation }\end{array}$ & $\begin{array}{l}1.65 \pm 1.78 \mathrm{y}, \text { no } \\
\text { recurrence occurred in } \\
10 \text { patients }\end{array}$ \\
\hline Yang et al. (7) & 20 & $F(85 \%)$ & 53-74 & $\begin{array}{l}\text { Psychological } \\
\text { stress }\end{array}$ & $\begin{array}{l}\text { Chest pain, chest } \\
\text { tightness }\end{array}$ & $\begin{array}{l}\text { ST-SE: } 20 \text { cases, T-WI: } \\
13 \text { cases, QTc-IP: } 5 \\
\text { cases }\end{array}$ & $\begin{array}{l}\text { EF: } 30-41 \% \text {, The } \\
\text { ventricular wall motion } \\
\text { at the apical part of the } \\
\text { heart is weakened }\end{array}$ & $\begin{array}{l}\text { Left ventricular } \\
\text { angiography showed } \\
\text { spherical apex dilatation } \\
\text { and segmental ventricular } \\
\text { wall motion abnormality }\end{array}$ & $\begin{array}{l}1-3 \text { y, } 20 \text { patients were } \\
\text { followed up for } 1 \text { year } \\
\text { without recurrence, and } \\
8 \text { patients were followed } \\
\text { up for } 3 \text { years without } \\
\text { recurrence }\end{array}$ \\
\hline Wang (8) & 14 & $\mathrm{~F}(71.4 \%)$ & $41-79$ & $\begin{array}{l}\text { Subarachnoid } \\
\text { hemorrhage }\end{array}$ & $\begin{array}{l}\text { Chest tightness, Chest } \\
\text { pain, dyspnea, fainting }\end{array}$ & $\begin{array}{l}\text { ST-SE: } 7 \text { cases, ST-SD: } \\
3 \text { cases, T-WI: } 11 \\
\text { cases, QTc-IP: } 5 \text { cases }\end{array}$ & $\begin{array}{l}\text { EF: } 36.07 \pm 6.15 \% \text {, left } \\
\text { ventricular apical and } \\
\text { middle systolic } \\
\text { dysfunction }\end{array}$ & $\begin{array}{l}\text { Left ventricular } \\
\text { angiography was not } \\
\text { performed }\end{array}$ & $\begin{array}{l}1 \mathrm{~m}, \text { no recurrence } \\
\text { occurred in } 14 \text { patients }\end{array}$ \\
\hline Yi and Ye (9) & 8 & $F(75 \%)$ & $30-71$ & $\begin{array}{l}\text { ES: } 3 \text { cases, FS: } 5 \\
\text { cases }\end{array}$ & $\begin{array}{l}\text { Chest pain, fainting, } \\
\text { difficulty breathing }\end{array}$ & $\begin{array}{l}\text { ST-SE: } 2 \text { cases, ST-SD: } \\
6 \text { cases, T-WI: } 4 \text { cases }\end{array}$ & $\begin{array}{l}\text { EF: } 30-40 \%, 4 \text { cases } \\
\text { of left ventricular wall } \\
\text { motion abnormality, } 3 \\
\text { cases of apical } \\
\text { balloonoid change }\end{array}$ & $\begin{array}{l}\text { Left ventricular } \\
\text { angiography indicated } \\
\text { Lvef } 40 \%-50 \% \text {, } \\
\text { weakened ventricular wall } \\
\text { and apex movement }\end{array}$ & $\begin{array}{l}21 \text { d, LVEF and } \\
\text { ventricular wall motion } \\
\text { returned to normal }\end{array}$ \\
\hline
\end{tabular}


TABLE 1 | Continued

\begin{tabular}{|c|c|c|c|c|c|c|c|c|c|}
\hline References & Cases & Gender & Age & Incentive & Symptoms & ECG & UCG & LVG & Follow up \\
\hline $\begin{array}{l}\text { Gan and Zhang } \\
\text { (10) }\end{array}$ & 10 & $\mathrm{~F}(90 \%)$ & $50-81$ & $\begin{array}{l}\text { ES: } 8 \text { cases, FS: } 2 \\
\text { cases }\end{array}$ & $\begin{array}{l}\text { Chest pain, chest } \\
\text { tightness, dyspnea and } \\
\text { fainting }\end{array}$ & $\begin{array}{l}\text { ST-SE: } 8 \text { cases, ST-SD: } \\
2 \text { cases, T-WI: } 8 \text { cases, } \\
\text { QTc-IP: } 5 \text { cases }\end{array}$ & $\begin{array}{l}\text { EF: } 25-41 \% \text {, } \\
\text { disappeared apical } \\
\text { motion in } 5 \text { cases, } \\
\text { weakened motion in } 5 \\
\text { cases, balloon-like } \\
\text { change in } 3 \text { cases, and } \\
\text { contradictory motion in } \\
7 \text { cases }\end{array}$ & $\begin{array}{l}\text { Left ventricular } \\
\text { angiography showed that } \\
\text { the apex of the left } \\
\text { ventricle was bulbous } \\
\text { and the apex motion was } \\
\text { weakened or } \\
\text { disappeared }\end{array}$ & $\begin{array}{l}8-12 \mathrm{~m} \text {, no recurrence } \\
\text { occurred in } 10 \text { patients }\end{array}$ \\
\hline Le (11) & 15 & $F(80 \%)$ & $38-72$ & $\begin{array}{l}\text { ES: } 6 \text { cases, FS: } 9 \\
\text { cases }\end{array}$ & $\begin{array}{l}\text { Chest pain, fainting, } \\
\text { difficulty breathing }\end{array}$ & $\begin{array}{l}\text { ST-SE: } 7 \text { cases, T-WI: } 8 \\
\text { cases }\end{array}$ & $\begin{array}{l}\text { The apical and middle } \\
\text { parts of the left } \\
\text { ventricle showed } \\
\text { balloon-like changes, } \\
\text { and the motion was } \\
\text { obviously weakened or } \\
\text { disappeared or showed } \\
\text { contradictory motion }\end{array}$ & $\begin{array}{l}\text { Coronary angiography } \\
\text { was performed in } 6 \\
\text { cases and CTA was } \\
\text { performed in } 9 \text { cases, } \\
\text { and no significant } \\
\text { coronary artery stenosis } \\
\text { was observed }\end{array}$ & $\mathrm{N}$ \\
\hline Hou (12) & 9 & $F(77.8 \%)$ & 68.44 & $\begin{array}{l}\text { ES: } 4 \text { cases, FS: } 2 \\
\text { cases }\end{array}$ & $\begin{array}{l}\text { Chest tightness, chest } \\
\text { pain, transient } \\
\text { confusion }\end{array}$ & $\begin{array}{l}\text { ST-SE: } 4 \text { cases, ST-SD: } \\
2 \text { cases, T-WI with } \\
\text { QTc-IP: } 1 \text { cases }\end{array}$ & $\begin{array}{l}\text { There were } 4 \text { cases of } \\
\text { segmental ventricular } \\
\text { wall motion decrease, } \\
\text { and the remaining } 5 \\
\text { cases showed left } \\
\text { ventricular motion } \\
\text { decrease or left } \\
\text { ventricular systolic } \\
\text { (diastolic) function } \\
\text { decrease }\end{array}$ & $\begin{array}{l}\text { Left ventricular } \\
\text { angiography showed } \\
\text { spherical apex dilatation } \\
\text { in } 1 \text { case, disappearance } \\
\text { of apex activity in } 1 \text { case, } \\
\text { and weakening of } \\
\text { anterior wall and apex } \\
\text { activity in } 1 \text { case }\end{array}$ & $\begin{array}{l}3 \mathrm{~m}-2 \mathrm{y}, 1 \text { case died, } 4 \\
\text { cases had no recurrence, } \\
\text { and } 1 \text { case was lost to } \\
\text { follow-up }\end{array}$ \\
\hline Hu et al. (13) & 10 & $F(80 \%)$ & $28-72$ & $\begin{array}{l}\text { ES: } 5 \text { cases, FS: } 5 \\
\text { cases }\end{array}$ & $\begin{array}{l}\text { Chest pain, difficulty } \\
\text { breathing }\end{array}$ & $\begin{array}{l}\text { ST-SE: } 7 \text { cases, ST-SD: } \\
2 \text { cases, T-WI: } 1 \text { cases }\end{array}$ & $\begin{array}{l}\text { EF: } 15-39 \% \text {. Absence } \\
\text { of apical movement or } \\
\text { reverse movement }\end{array}$ & $\begin{array}{l}\text { Four cases of left } \\
\text { ventricular angiography } \\
\text { showed that the apex of } \\
\text { the heart was spherical } \\
\text { dilatation, and the } \\
\text { movement was obviously } \\
\text { weakened or } \\
\text { disappeared }\end{array}$ & $\begin{array}{l}7-10 \mathrm{~d} \text {, LVEF and } \\
\text { ventricular wall } \\
\text { movement returned to } \\
\text { normal }\end{array}$ \\
\hline $\begin{array}{l}\text { Jiang and Ning } \\
\text { (14) }\end{array}$ & 20 & $F(80 \%)$ & $47-63$ & $\begin{array}{l}\text { ES: } 10 \text { cases, PS: } \\
10 \text { cases }\end{array}$ & $\begin{array}{l}\text { Chest pain, difficulty } \\
\text { breathing }\end{array}$ & ST-SE: 14 cases & $\begin{array}{l}\text { EF: } 28 \% \text {, absence of } \\
\text { apical movement }\end{array}$ & $\begin{array}{l}\text { Left ventricular } \\
\text { angiography showed } \\
\text { bulbous apex dilatation }\end{array}$ & $\begin{array}{l}7-1 \text { Od, LVEF and } \\
\text { ventricular wall } \\
\text { movement returned to } \\
\text { normal }\end{array}$ \\
\hline $\operatorname{Li}(15)$ & 12 & $F(83.3 \%)$ & $23-67$ & $\begin{array}{l}\text { ES: } 8 \text { cases, FS: } 4 \\
\text { cases }\end{array}$ & $\begin{array}{l}\text { Chest pain, fainting, } \\
\text { chest tightness, } \\
\text { palpitations, dyspnea }\end{array}$ & $\begin{array}{l}\text { ST-SE with T-WI: } 8 \\
\text { cases, ST-SD: } 2 \text { cases }\end{array}$ & $\begin{array}{l}\text { EF: } 30-45 \% \text {, } \\
\text { weakened ventricular } \\
\text { wall motion in } 7 \text { cases, } \\
\text { contradictory motion in } \\
3 \text { cases, and bulbous } \\
\text { apex dilatation in } 2 \\
\text { cases }\end{array}$ & $\begin{array}{l}\text { Left ventricular } \\
\text { angiography showed } \\
\text { bulbous apex dilatation }\end{array}$ & $\begin{array}{l}1 \mathrm{~m}, \mathrm{LVEF} \text { and ventricular } \\
\text { wall movement returned } \\
\text { to normal }\end{array}$ \\
\hline
\end{tabular}


TABLE 1 | Continued

\begin{tabular}{|c|c|c|c|c|c|c|c|c|c|}
\hline References & Cases & Gender & Age & Incentive & Symptoms & ECG & UCG & LVG & Follow up \\
\hline Han et al. (16) & 16 & $F(87.5 \%)$ & N & $\begin{array}{l}\text { ES: } 6 \text { cases, FS: } \\
10 \text { cases }\end{array}$ & $\begin{array}{l}\text { Chest pain, retrosternal } \\
\text { pain, chest tightness }\end{array}$ & $\begin{array}{l}\text { ST-SE: } 8 \text { cases, T-WI: } 8 \\
\text { cases }\end{array}$ & $\begin{array}{l}\text { The apical and middle } \\
\text { parts of the left ventricle } \\
\text { showed balloon-like } \\
\text { changes, and the wall } \\
\text { motion was obviously } \\
\text { weakened or } \\
\text { disappeared }\end{array}$ & $\begin{array}{l}\text { Coronary angiography } \\
\text { showed no significant } \\
\text { coronary stenosis }\end{array}$ & $\begin{array}{l}2-4 \mathrm{w} \text {, ventricular wall } \\
\text { movement returned to } \\
\text { normal }\end{array}$ \\
\hline Lu et al. (17) & 8 & $F(75 \%)$ & $40-76$ & $\begin{array}{l}\text { ES: } 5 \text { cases, FS: } 3 \\
\text { cases }\end{array}$ & $\begin{array}{l}\text { Chest pain, weakness, } \\
\text { palpitations, difficulty } \\
\text { breathing }\end{array}$ & $\begin{array}{l}\text { ST-SE: } 6 \text { cases, T-WI: } 2 \\
\text { cases, QTC-IP: } 5 \text { cases }\end{array}$ & $\begin{array}{l}\text { EF: } 27-40 \%, 5 \text { cases } \\
\text { showed bulbous } \\
\text { dilatation at the apex or } \\
\text { middle of the heart and } \\
\text { uncoordinated } \\
\text { movement of the } \\
\text { ventricular wall }\end{array}$ & $\begin{array}{l}\text { Coronary angiography } \\
\text { was normal in } 6 \text { cases, } \\
\text { and single coronary } \\
\text { artery stenosis in } 2 \text { cases } \\
\text { was } 30 \text { and } 50 \% \text {, } \\
\text { respectively }\end{array}$ & $\begin{array}{l}1 \mathrm{~m} \text {, LVEF and ventricular } \\
\text { wall movement returned } \\
\text { to normal }\end{array}$ \\
\hline Feng et al. (18) & 52 & $F(84.6 \%)$ & 30-82 & $\begin{array}{l}\text { ES: } 26 \text { cases, FS: } \\
5 \text { cases, ES and } \\
\text { FS: } 5 \text { cases }\end{array}$ & $\begin{array}{l}\text { Chest pain, dyspnea, } \\
\text { chest tightness, } \\
\text { palpitations, fainting }\end{array}$ & $\begin{array}{l}\text { ST-SE: } 48 \text { cases, T-WI: } \\
22 \text { cases, QTc-IP: } 5 \\
\text { cases }\end{array}$ & $\begin{array}{l}\text { EF: } 21-54 \%, 38 \text { cases } \\
\text { showed spherical } \\
\text { expansion of the apex } \\
\text { of the left ventricle, } \\
\text { weakened or } \\
\text { disappeared movement }\end{array}$ & $\begin{array}{l}30 \text { cases of left } \\
\text { ventricular angiography } \\
\text { showed that the apex of } \\
\text { the heart was spherical } \\
\text { dilatation during systolic } \\
\text { period, and the } \\
\text { myocardial systolic } \\
\text { activities disappeared or } \\
\text { significantly weakened }\end{array}$ & $\begin{array}{l}3 \mathrm{~m}-5 \mathrm{y} \text {, some patients } \\
\text { were followed up for } 3-1 \\
\text { years without recurrence, } \\
\text { and } 1 \text { patient was } \\
\text { followed up for nearly } 5 \\
\text { years without recurrence }\end{array}$ \\
\hline Li et al. (19) & 13 & $F(38.5 \%)$ & $\begin{array}{c}50.9 \pm \\
15.8\end{array}$ & $\begin{array}{l}\text { Subarachnoid } \\
\text { hemorrhage }\end{array}$ & $\begin{array}{l}\text { Chest pain, fainting, } \\
\text { difficulty breathing }\end{array}$ & ST-SE and T-WI & $\begin{array}{l}\text { The movement of the } \\
\text { left ventricular wall was } \\
\text { weakened or } \\
\text { disappeared, and the } \\
\text { apex of the heart was } \\
\text { dilated like a ball }\end{array}$ & $\begin{array}{l}\text { No corresponding } \\
\text { vascular infarction was } \\
\text { observed, and mild } \\
\text { coronary stenosis may be } \\
\text { present in elderly patients }\end{array}$ & $\mathrm{N}$ \\
\hline
\end{tabular}

F, female; ECG, electrocardiogram; UCG, echocardiography; LVG, left ventricular angiography.

${ }^{\star} E S$, emotional stress; " $P S$, physical stress; ${ }^{a} S T$-SE, ST-segment elevation; ${ }^{b} T$-S, ST segment depression; ${ }^{c} T$-WI, T-wave inversion; ${ }^{d}$ QTC-IP, QTc interval prolongation. 
TABLE 2 | Comparative analysis of clinical characteristics of 9 patients.

\begin{tabular}{|c|c|c|c|c|c|c|c|c|c|c|c|}
\hline Patient & Sex & Age & Symptoms & Onset time & Duration & Inducement & Location & Characteristic & $\begin{array}{l}\text { Aggravating or } \\
\text { mitigating factors }\end{array}$ & $\begin{array}{l}\text { Accompanying } \\
\text { symptoms }\end{array}$ & Follow-up \\
\hline 1 & M & 38 & Syncope & $4 \mathrm{~h}$ & None & None & None & None & None & None & $\begin{array}{l}50 \text { months, LVEF recovered from } \\
41.3 \text { to } 62 \% \text {, no recurrence } \\
\text { occurred }\end{array}$ \\
\hline 2 & $\mathrm{~F}$ & 42 & Chest pain & 3 days & $2 \mathrm{~h}$ & Emotional stress & Precordial area & Squeezed & $\begin{array}{l}\text { Symptoms relieved } \\
\text { after taking } 2 \text { capsules } \\
\text { of suxiaojiuxin pills }\end{array}$ & $\begin{array}{l}\text { Palpitation, nausea, } \\
\text { vomiting }\end{array}$ & $\begin{array}{l}47 \text { months, the admission LVEF } \\
\text { was } 63 \% \text {, no recurrence } \\
\text { occurred }\end{array}$ \\
\hline 3 & $\mathrm{~F}$ & 42 & Chest pain & 1 day & $10 \mathrm{~min}$ & Emotional stress & Precordial area & Needle stick & $\begin{array}{l}\text { Can be relieved after } \\
\text { rest }\end{array}$ & Dizziness, tinnitus & $\begin{array}{l}33 \text { months, the admission LVEF } \\
\text { was } 67 \% \text { and follow-up LVEF } \\
\text { was } 65 \% \text {, no recurrence } \\
\text { occurred }\end{array}$ \\
\hline 4 & $\mathrm{~F}$ & 60 & Chest pain & $4 \mathrm{~h}$ & $1 \mathrm{~h}$ & Emotional stress & $\begin{array}{l}\text { Behind the } \\
\text { sternum }\end{array}$ & Squeezed & No relief after rest & Flustered & $\begin{array}{l}21 \text { months, the admission LVEF } \\
\text { was } 62.4 \% \text {, no recurrence } \\
\text { occurred }\end{array}$ \\
\hline 5 & $\mathrm{~F}$ & 37 & Chest pain & 10 days & A few hours & Emotional stress & Precordial area & Compressed, stuffy & $\begin{array}{l}\text { Increased after upper } \\
\text { respiratory tract } \\
\text { infection }\end{array}$ & $\begin{array}{l}\text { Dizziness, vomiting, } \\
\text { shock }\end{array}$ & $\begin{array}{l}17 \text { months, the admission LVEF } \\
\text { was } 66 \% \text {, no recurrence } \\
\text { occurred }\end{array}$ \\
\hline 6 & $\mathrm{M}$ & 36 & Chest tightness & 1 day & $1 \mathrm{~h}$ & Physical stress & Precordial area & Tight & None & $\begin{array}{l}\text { Headache, nausea, } \\
\text { back discomfort }\end{array}$ & $\begin{array}{l}16 \text { months, the admission LVEF } \\
\text { was } 60 \% \text {, no recurrence } \\
\text { occurred }\end{array}$ \\
\hline 7 & M & 34 & Shoulder pain & 1day & $1 \mathrm{~h}$ & Emotional stress & $\begin{array}{l}\text { Shoulders, neck, } \\
\text { and behind the } \\
\text { breastbone }\end{array}$ & Relief after activity & Relief after activity & None & $\begin{array}{l}14 \text { months, the admission LVEF } \\
\text { was } 63 \% \text { and follow-up LVEF } \\
\text { was } 63 \% \text {, no recurrence } \\
\text { occurred. }\end{array}$ \\
\hline 8 & $\mathrm{~F}$ & 50 & Chest pain & 9 days & $0.5 \mathrm{~h}$ & None & $\begin{array}{l}\text { Middle and } \\
\text { posterior sternum }\end{array}$ & Compressed & $\begin{array}{l}\text { Relief after oral suxiao } \\
\text { jiuxin pill }\end{array}$ & $\begin{array}{l}\text { Shortness of breath, } \\
\text { numbness and } \\
\text { weakness in hands }\end{array}$ & $\begin{array}{l}9 \text { months, the admission LVEF } \\
\text { was } 65 \% \text {, no recurrence } \\
\text { occurred }\end{array}$ \\
\hline 9 & $\mathrm{~F}$ & 79 & Chest discomfort & $8 \mathrm{~h}$ & Not relieved & Emotional stress & Precordial area & Relief after rest & Relief after rest & Suffocated & $\begin{array}{l}9 \text { months, the admission LVEF } \\
\text { was } 58.96 \% \text {, no recurrence } \\
\text { occurred }\end{array}$ \\
\hline
\end{tabular}


TABLE 3 | Comparative analysis of blood routine of 7 patients before and after admission.

\begin{tabular}{|c|c|c|c|c|c|}
\hline & Admitted & Discharged & $\boldsymbol{t}$ 值 & $95 \% \mathrm{Cl}$ & $\boldsymbol{P}$ \\
\hline WBC & $10.59 \pm 4.94$ & $8.02 \pm 3.37$ & 3.2 & $0.61-4.54$ & 0.02 \\
\hline RBC & $4.68 \pm 0.62$ & $4.66 \pm 0.55$ & 0.214 & $0.24-0.29$ & 0.84 \\
\hline Hemoglobin & $135.57 \pm 16.49$ & $134.86 \pm 15.23$ & 0.272 & $-5.71-7.14$ & 0.79 \\
\hline Platelet & $253.57 \pm 95.83$ & $232.00 \pm 101.39$ & 2.337 & $-1.00-43.58$ & 0.06 \\
\hline The percentage of neutrophils & $78.39 \pm 11.27$ & $69.21 \pm 14.12$ & 1.598 & $-4.87-23.21$ & 0.16 \\
\hline Percentage of lymphocytes & $14.71 \pm 10.49$ & $21.24 \pm 8.19$ & -1.745 & $-15.68-2.62$ & 0.13 \\
\hline Percentage of monocytes & $6.41 \pm 3.25$ & $8.14 \pm 6.42$ & -0.852 & $-6.69-3.23$ & 0.43 \\
\hline Percentage of eosinophils & $0.27 \pm 0.36$ & $1.04 \pm 1.07$ & -1.861 & $-1.79-0.24$ & 0.11 \\
\hline Percentage of basophils & $0.21 \pm 0.12$ & $0.36 \pm 0.19$ & -1.594 & $-0.36-0.08$ & 0.16 \\
\hline Neutrophils count & $8.54 \pm 4.58$ & $5.81 \pm 3.39$ & 2.664 & $0.22-5.23$ & 0.04 \\
\hline Lymphocyte count & $1.32 \pm 0.65$ & $1.54 \pm 0.49$ & -0.926 & $-0.79-0.36$ & 0.39 \\
\hline Monocyte count & $0.69 \pm 0.59$ & $0.57 \pm 0.35$ & 0.578 & $0.42-0.68$ & 0.58 \\
\hline Eosinophil count & $0.02 \pm 0.02$ & $0.06 \pm 0.05$ & -1.875 & $-0.11-0.01$ & 0.11 \\
\hline Basophil count & $0.02 \pm 0.01$ & $0.03 \pm 0.01$ & -0.934 & $-0.02-0.01$ & 0.39 \\
\hline Hematocrit & $41.01 \pm 5.36$ & $40.73 \pm 3.99$ & 0.341 & $-1.76-2.34$ & 0.75 \\
\hline Mean erythrocyte volume & $87.71 \pm 3.37$ & $87.66 \pm 3.46$ & 0.069 & $-1.97-2.08$ & 0.95 \\
\hline Mean hemoglobin & $29.03 \pm 1.67$ & $28.98 \pm 1.53$ & 0.183 & $-0.53-0.62$ & 0.86 \\
\hline Average hemoglobin concentration & $331.00 \pm 9.98$ & $330.86 \pm 10.02$ & 0.049 & $-6.97-7.26$ & 0.96 \\
\hline Red blood cell distribution width & $12.81 \pm 0.64$ & $12.93 \pm 0.79$ & -0.745 & $-0.49-0.26$ & 0.48 \\
\hline Mean platelet volume & $10.93 \pm 1.18$ & $11.06 \pm 1.35$ & -0.721 & $-0.56-0.31$ & 0.5 \\
\hline Thrombocytopenia & $0.27 \pm 0.08$ & $4.06 \pm 10.12$ & -0.992 & $-13.15-5.56$ & 0.36 \\
\hline Width of platelet distribution & $13.16 \pm 2.64$ & $13.38 \pm 3.45$ & -0.357 & $-1.77-1.32$ & 0.73 \\
\hline
\end{tabular}

$P<0.05$ was considered statistically significant.

had other diseases, and its influence on stress cardiomyopathy could not be excluded; Exclusion case report; Exclusion of cases $\leq 5$; Exclude by title and abstract. From 8 dimensions of "gender, age, risk factors, symptoms, ECG, UCG, LVG, and followup" through literature retrieval, the clinical characteristics in each dimension were statistically summarized. A total of 154 literatures were initially examined. According to the inclusion and exclusion criteria, 18 literatures were finally included, including 264 cases, as shown in Figure 1. The literature retrieval process was shown in Figure 1, and the clinical characteristics were shown in Table $\mathbf{1}$.

\section{RESULTS}

\section{Basic Information}

Among the 9 patients with a definite diagnosis of Takotsubo syndrome, 3 cases $(33.3 \%)$ were male, and 6 cases $(66.7 \%)$ were female. In this study, the mean age of onset was 46.4 years old, the median age was 42 years old, 6 patients $(66.7 \%)$ were $\leq 42$ years old, 3 patients $(33.3 \%)$ were 42 years old, and 2 patients $(22.2 \%)$ were elderly ( $\geq 60$ years). The median time from onset to treatment was 1 day, the shortest time was $4 \mathrm{~h}$, and the longest time was 5 years. All patients were treated in the emergency department. There were 2 cases of hypertension, 1 case of diabetes, 1 case of abnormal glucose tolerance, and no patients with related medical history. There were 5 cases in spring, 1 case in summer and 1 case in autumn, and 2 cases in winter. Two patients lived in rural areas, and seven lived in urban areas. None of the above patients had a genetic history of related diseases.

\section{Clinical Manifestations of Initial Diagnosis}

All patients came to the hospital on emergency. The main symptom was chest pain for 8 patients $(88.9 \%)$ who came to the hospital, and 1 patient went to the hospital because of syncope. Among them, 7 cases $(77.8 \%)$ were mainly caused by emotional fluctuations or mental stimulation. Among the remaining 2 cases, 1 case developed chest pain without a known cause, and the other case was admitted to the hospital for syncope without a known cause. Seven cases $(77.8 \%)$ had pain mainly in the precardiac area, one case had pain in the shoulder area, and one case was admitted to the hospital due to syncope, the cause of which was not known. In patients with chest pain symptoms, the nature of chest pain was compression, needle or contraction like, with a median duration of $1 \mathrm{~h}$. The longest duration of symptoms was that the pain was never relieved, and the shortest duration of pain was 3-5 min. Among the alleviating and aggravating factors, 2 cases $(22.2 \%)$ reported that their symptoms were relieved after oral administration of suxiaojiuxin pills or nitroglycerin and other vasodilators, and 2 cases reported that their symptoms were relieved after rest. Among the accompanying symptoms, 2 patients developed shortness of breath, 3 patients developed nausea and vomiting, 3 patients developed dizziness and headache, and 1 patient developed shock. In the course of diagnosis and treatment, 6 patients visited our emergency department for the first time because of the 
TABLE 4 | Comparative analysis of biochemical indexes of 5 patients before and after admission.

\begin{tabular}{|c|c|c|c|c|c|}
\hline & Admitted & Discharged & $\boldsymbol{t}$ 值 & $95 \% \mathrm{Cl}$ & $P$ \\
\hline K & $4.07 \pm 0.78$ & $3.88 \pm 0.27$ & 0.51 & $-0.82-1.19$ & 0.64 \\
\hline $\mathrm{Na}$ & $142.56 \pm 13.82$ & $137.04 \pm 3.85$ & 0.90 & $-11.48-22.53$ & 0.42 \\
\hline$C L$ & $104.20 \pm 2.83$ & $106.20 \pm 4.04$ & -1.59 & $-5.49-1.49$ & 0.19 \\
\hline Ga & $2.21 \pm 0.18$ & $2.26 \pm 0.12$ & -0.59 & $-0.29-0.19$ & 0.59 \\
\hline Uric acid & $4.02 \pm 2.17$ & $3.83 \pm 1.42$ & 0.30 & $-2.74-3.31$ & 0.78 \\
\hline Aspartate aminotransferase & $40.67 \pm 32.19$ & $55.15 \pm 39.73$ & -0.69 & $-73.12-44.16$ & 0.53 \\
\hline Lactate dehydrogenase & $177.64 \pm 72.56$ & $161.35 \pm 27.73$ & 0.74 & $-74.26-118.94$ & 0.52 \\
\hline Creatine kinase & $276.06 \pm 376.22$ & $120.99 \pm 118.84$ & 0.90 & $-323.02-633.17$ & 0.42 \\
\hline Creatine kinase isoenzyme & $17.49 \pm 13.63$ & $12.84 \pm 8.34$ & 0.72 & $-13.24-22.53$ & 0.51 \\
\hline Troponin & $0.03 \pm 0.04$ & $0.01 \pm 0.02$ & 1.23 & $-0.05-0.08$ & 0.34 \\
\hline $\mathrm{CRP}^{\#}$ & $15.81 \pm 23.39$ & $0.62 \pm 0.24$ & 2.24 & $-1.09-1.57$ & 0.27 \\
\hline
\end{tabular}

${ }^{*} B N P$, N-terminal B-type natriuretic peptide precursor; ${ }^{\#}$ CRP, Hypersensitive C-reactive protein; $P<0.05$ was considered statistically significant.

disease, and the remaining 3 patients were transferred to our emergency department after visiting a local hospital. Regarding surgical history of the patients, 7 cases $(77.8 \%)$ had no previous operations, 1 case received surgical treatment for a hepatic hydatid, and 1 case received surgical treatment for gallstones. One patient had a history of a tuberculosis infection and has now been cured. Among the 9 patients, 3 patients (33.3\%) smoked, including 2 males and 1 female. A total of 2 people drank alcohol, all of them were male, and all of them drank alcohol occasionally. Among the vital signs, 9 patients had normal body temperatures and respiratory rates, 2 had rapid heart rates, 1 had shock, 7 were overweight with a high body mass index, 1 was a woman with a low body weight, and 1 was a woman with normal weight, as shown in Table 2.

\section{Hematological Examination}

In all 9 patients, the complete hematological examination included routine blood, biochemical, myocardial enzymes, troponin levels, myoglobin levels, BNP levels, inflammatory indexes and other routine indexes, tests for thyroid function. Testing for a partial improvement of thyroid function, testing for eight types of viruses, including coxsackie virus, EpsteinBarr virus and other indexes. In the routine blood examinations, the white blood cell counts of 7 patients were at normal levels, 2 patients had increased levels, 5 patients had an increased percentages of neutrophils, and 3 patients had an increased percentage of monocytes. On the electrolyte test, 4 cases had hypokalemia and 6 cases had hyponatremia. One case had acute renal insufficiency, 1 case had acute left heart failure, 1 case had high triglycerides, and 1 case had a level of low density lipoprotein on the high end of normal. There were 5 cases with creatine kinase elevations, 3 cases with creatine kinase isoenzymes, 2 cases of high troponin levels, 3 cases with different levels of interleukin
-6 and the rise of hypersensitive c-reactive protein, and 1 case with subclinical hypothyroidism. Virus 8, Coxsackie virus, and Epstein-Barr virus tests were negative. A paired T-test was performed on the routine blood tests before and after admission, and only the counts of the white blood cells and the neutrophils were statistically significant in the comparison (see Tables 3, 4).

\section{Imaging Examination}

Among the imaging examinations conducted during the hospitalization of the patients, 3 patients had a complete myocardial radionuclide examination, 1 patient had a decreased left ventricular wall motion, and 1 patient had a decreased LVEF. Case 1 was hospitalized due to syncope, and no obvious abnormalities were found in pulmonary artery CTA, brain NMR and brain enhanced NMR, as shown in Figure 2.

\section{Coronary Angiography}

All 9 patients underwent emergency coronary angiography. Case 1 had slow coronary blood flow; and $30 \%$ of the patients with LAD had proximal stenosis. In case $4,40 \%$ of the coronary LAD was narrowed. In case 9, the proximal LAD had a localized narrowing of $40 \%$, the middle RCA was narrowed by $30 \%$, and the whole LCX had a slow blood flow, as shown in Figure 3.

\section{ECG}

In the ECG examination, a paired $T$-test of objective ECG indexes from admission to discharge was conducted for 9 patients. The P wave time limit, QT, QTC, QRS time limit and P-R interval between admission and discharge were not statistically significant $(P>0.05)$. After characteristic analysis of the 9 cases of patients, we found that in cases 1 and 7 the ST was prolonged, in case 5, the ST segment was decreased and in cases $4,8,2$, and 9, there was an ST -T change. There were 9 cases of paroxysmal atrial flutter 


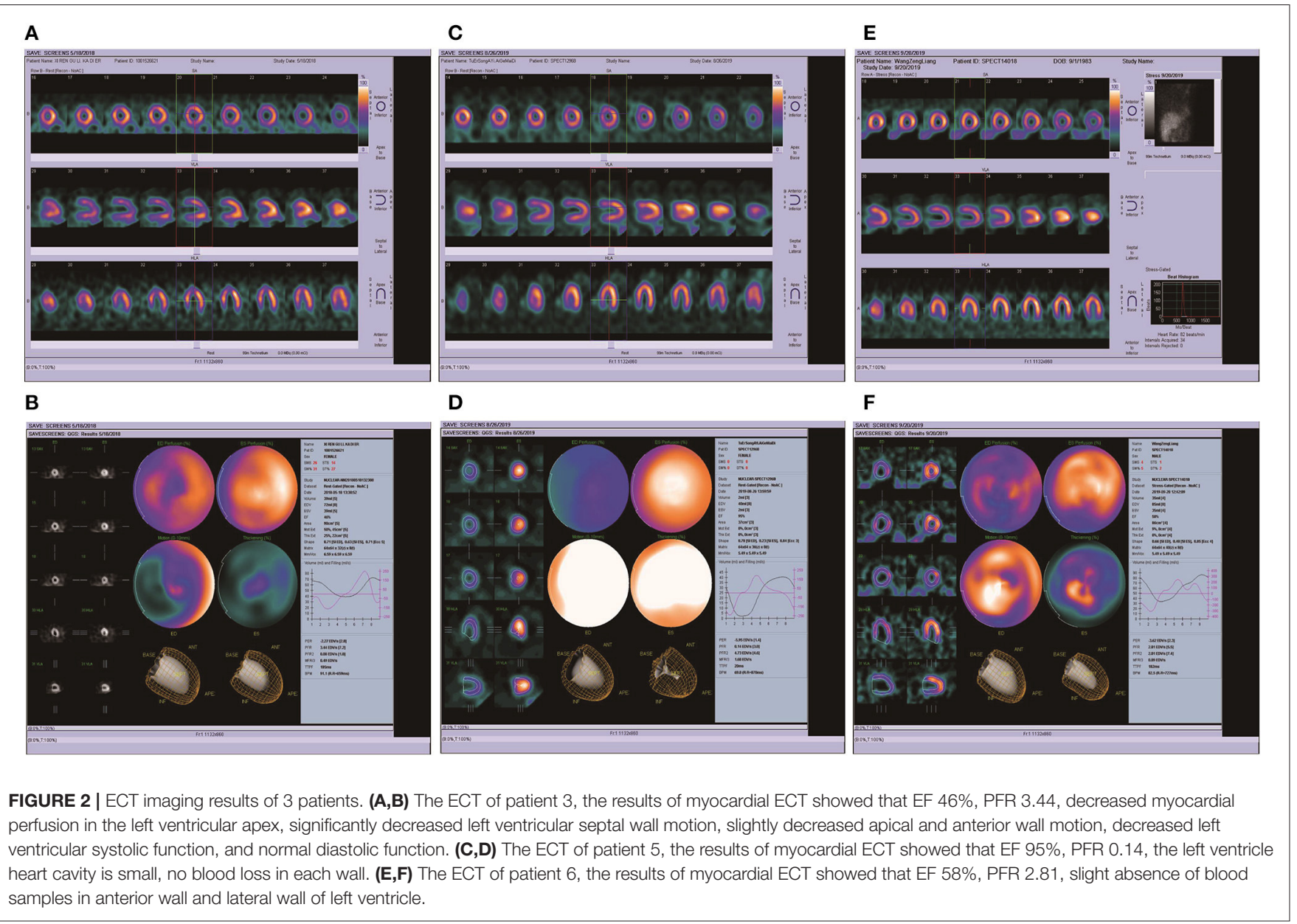

and paroxysmal atrial fibrillation. Patients 2, 3, 4, and 9 showed prolonged QTc interval in ECG examination, while the rest of the patients were normal. Objective indicators of ECG are shown in Table 5. ECG images are shown in Figures 4, 5.

\section{Ultrasound Examination of Cardiac and Cervical Vessels}

During the cardiac color ultrasound examination, the LVEF of Case 1 was significantly impaired with a weakened ventricular wall motion, but the ejection fraction returned to normal upon discharge. Aortic insufficiency was observed in case 4. Minor aortic regurgitation occurred in case 7 . In case 9, there was left atrium enlargement, reduced left ventricular muscle segmental motion, mitral valve insufficiency, aortic valve insufficiency, and mild pulmonary hypertension. Other patients showed different degrees of ventricular wall motion reduction. The ventricular wall movement gradually returned to normal during out-of-hospital follow-up. See Figure 6.

In the 9 patients, we found that, except for patients 1, 2, and 7 who did not receive cervical artery ultrasound, all the other patients had plaques located in the bifurcation of the innaminate artery and the right subclavicular artery to varying degrees, and the maximum plaques were $\sim 11.1 \times 1.8 \mathrm{~mm}$. See Figure 6, Color ultrasound of remaining neck vessels is shown in Figure 6.

\section{TREATMENT AND FOLLOW-UP}

For patients admitted to hospital for treatment of chest pain, the rise of the dynamic changes, the electrocardiogram (ECG) changes and rise in heart markers, the emergency department considered the possibility of coronary heart disease (CHD). Hence, the emergency departments considered performing emergency coronary angiography examinations, hospitalization and nutrition to improve myocardial blood flow, reduce myocardial oxygen consumption, and secondarily prevent coronary heart disease, and they performed other comprehensive treatments, The patient's symptoms were significantly improved at discharge from the hospital compared with those on admission. Of course, Takotsubo syndrome may also cause serious complications, such as heart failure, malignant arrhythmia, hemodynamics and other complications. Case 1 developed shock combined with acute renal failure, and Case 9 developed acute left heart 


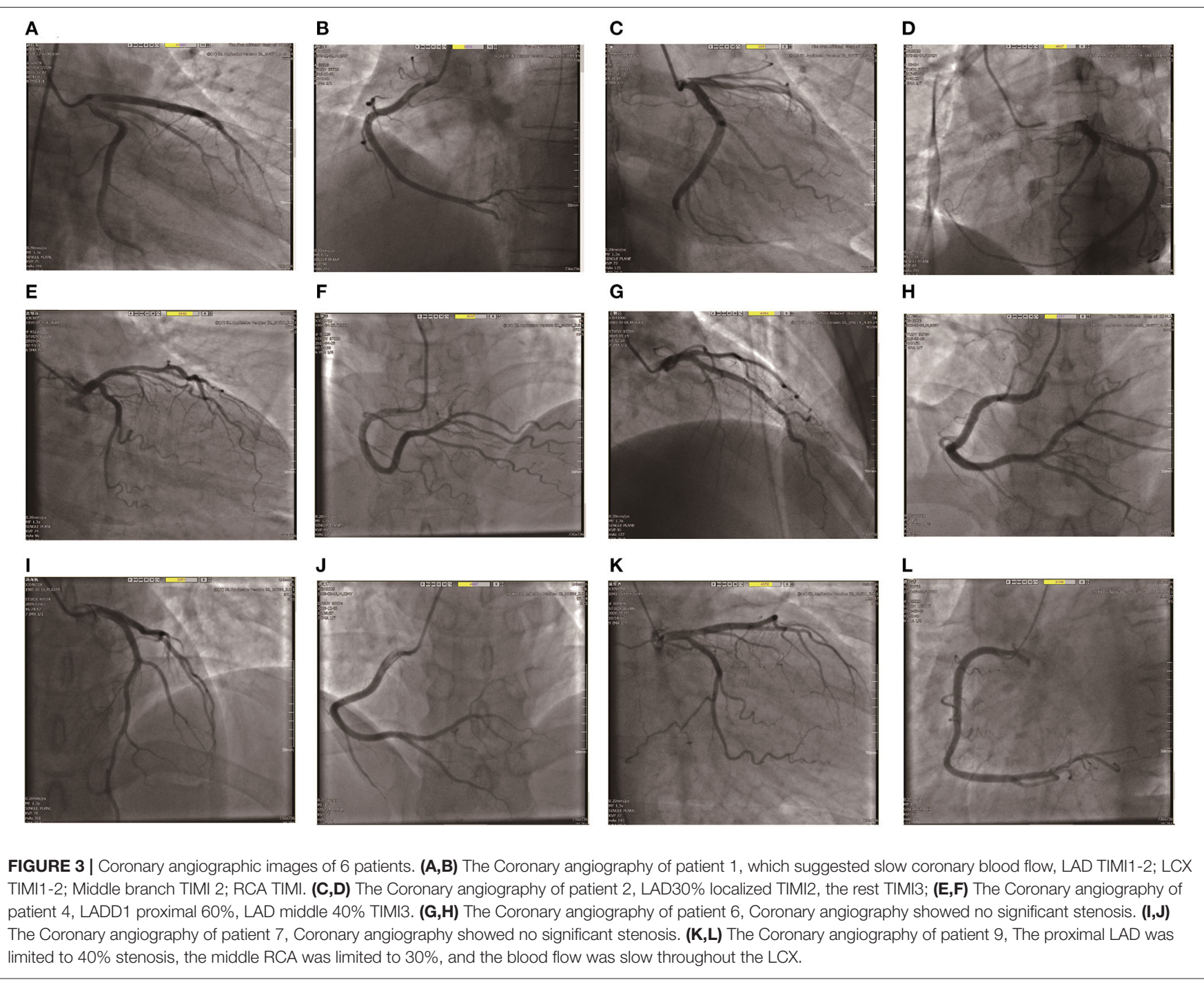

TABLE 5 | Comparison of P, QT, QTC, QRS, and P-R intervals in ECG of 6 patients before and after admission.

\begin{tabular}{lcccc}
\hline & Admitted & Discharged & $\boldsymbol{t}$ 值 & 95\% Cl \\
\hline P (ms) & $98.67 \pm 7.00$ & $98.67 \pm 11.98$ & 0 & $-18.54-18.54$ \\
QT (ms) & $334.33 \pm 95.55$ & $401.33 \pm 63.97$ & -1.06 & $-229.99-95.99$ \\
QTc (ms) & $402.67 \pm 92.31$ & $445.33 \pm 49.90$ & -0.81 & $-178.34-93.01$ \\
QRS (ms) & $81.83 \pm 19.76$ & $86.33 \pm 5.72$ & -0.49 & $-28.08-19.08$ \\
P-R (ms) & $160.00 \pm 22.31$ & $172.67 \pm 23.79$ & -1.77 & $-31.09-5.76$
\end{tabular}

$P<0.05$ was considered statistically significant.

failure accompanied by paroxytic atrial fibrillation, which improved after symptomatic treatment and was discharged. None of the 9 patients had any related complications or recurrence during the out-of-hospital follow-up. After discharge, due to the poor compliance of some patients, the patients stopped taking the medications, while some patients underwent medication adjustments under the guidance of doctors.

\section{DISCUSSION}

TTS was first described in 1990. Japanese scholar Dote et al. (20) reported the left ventricular angiographic images of 5 patients without obstructive coronary artery disease but with symptoms of myocardial infarction and defined it as TTS. The clinical symptoms and electrocardiogram manifestations of this syndrome are similar to those of acute coronary 
A

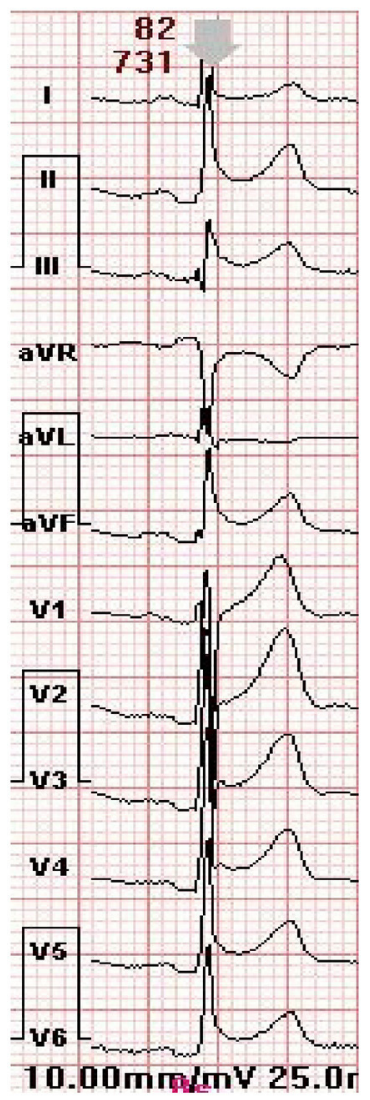

B

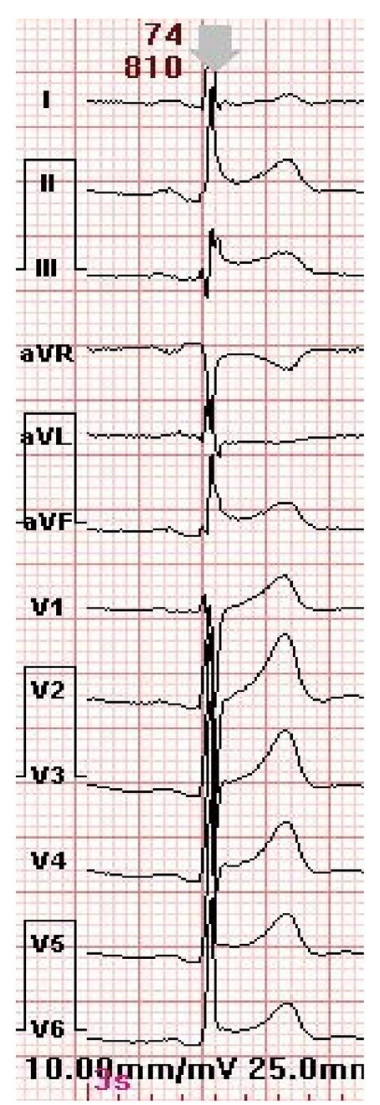

C

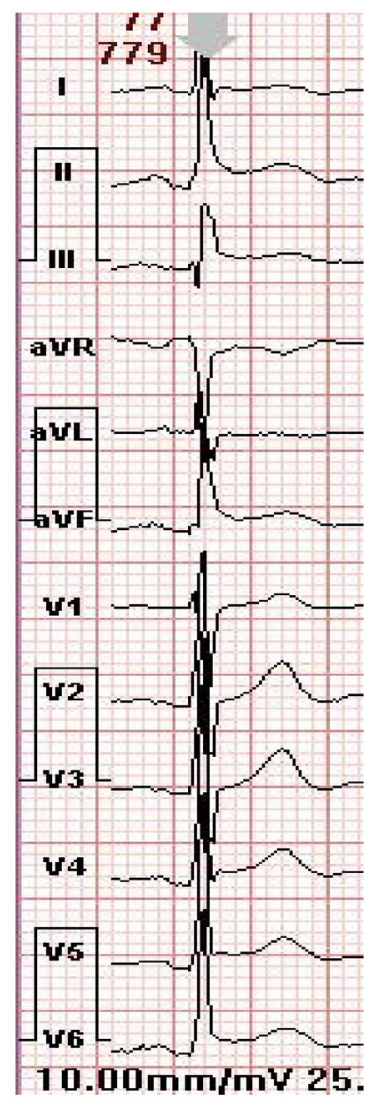

D

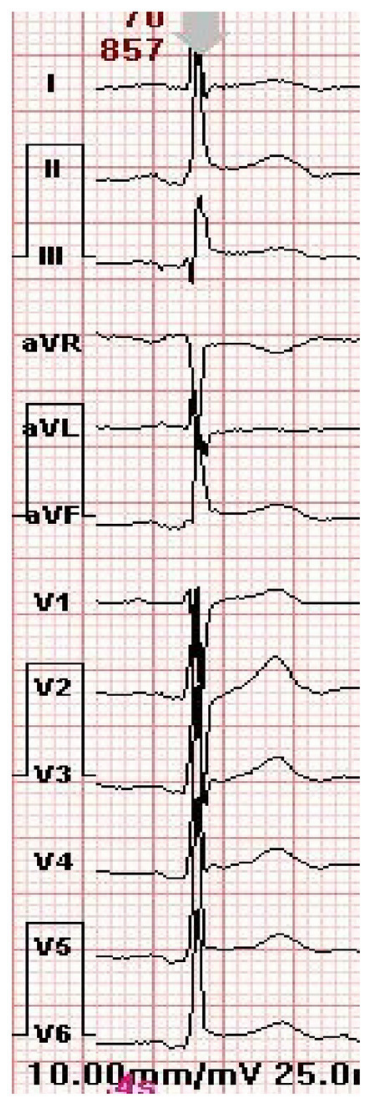

FIGURE 4 | ECG changes of patient 7 during hospitalization. (A) The electrocardiogram at admission. (B) The electrocardiogram on the first day of admission. (C) Electrocardiogram on the third day of admission. (D) The electrocardiogram before discharge.

syndrome. The main characteristic of this syndrome is regional abnormal left ventricular wall motion accompanied by abnormal left ventricular dilation during the systolic period. After the relevant inducement was removed, the cardiac function of the patient returned to normal, and the prognosis was generally good.

As research on TTS continues, an epidemiological study by Murugiah et al. (21) found that the incidence of TTS increased from 2.3 cases per 100,000 population years in 2007 to 7.1 cases per 100,000 population years in 2012. A study of 1,750 TTS by Templin et al. (22) found that $89.8 \%$ were female, with an average age of 67 years. TTS has been found to occur in children in some published case reports (2224). Among the TTS patients in this study, women accounted for $66.7 \%$ of cases. A total of 264 cases of TTS were seen in the Chinese population, among which women accounted for $78.8 \%$ of cases. The main reason may be that estrogen regulates sympathetic tension through the central action of the myocardium, vascular system and $\beta A R$ expression and contributes to the relative inhibition of $\beta A R$ expression during the female reproductive period. This sympathetic lytic effect of estrogen disappears after menopause, and the myocardial and vascular responses induced by $\beta A R$ agonists are enhanced. This may partly explain why TTS is most common in postmenopausal women (25).

The main causes of TTS are emotional stress or physical stress, and it has been found that pheochromocytoma, subarachnoid hemorrhage and other diseases can cause TTS. Sharkey et al. (23) followed up 136 TTS patients and found that 22 cases were related to physical stress, 15 of which had no obvious stress inducement. Wittstein et al. (26) found that catecholamine levels were higher in 19 TTS patients than in 7 Killipi II AMI patients. We think that emotional or physical stress activates the adrenal medulla in the human body, leading to an increased secretion of catecholamines in the human body, and increased catecholamine reduces the activity of cardiomyocytes through periodic calcium overload mediated by AMP 8, thus leading to a series of syndromes caused by a high catecholamine in patients.

Furthermore, we found that the main clinical symptoms of TTS patients were chest pain, including chest tightness, palpitations, dyspnea, syncope, fatigue and other symptoms. One reason for the symptoms of chest pain in patients includes the spasm of multiple coronary arteries. Dote et al. (20) believed that left ventricular dysfunction and myocardial shock are caused by spasms of multiple coronary arteries at the same time. A second reason could be due to coronary microvascular 


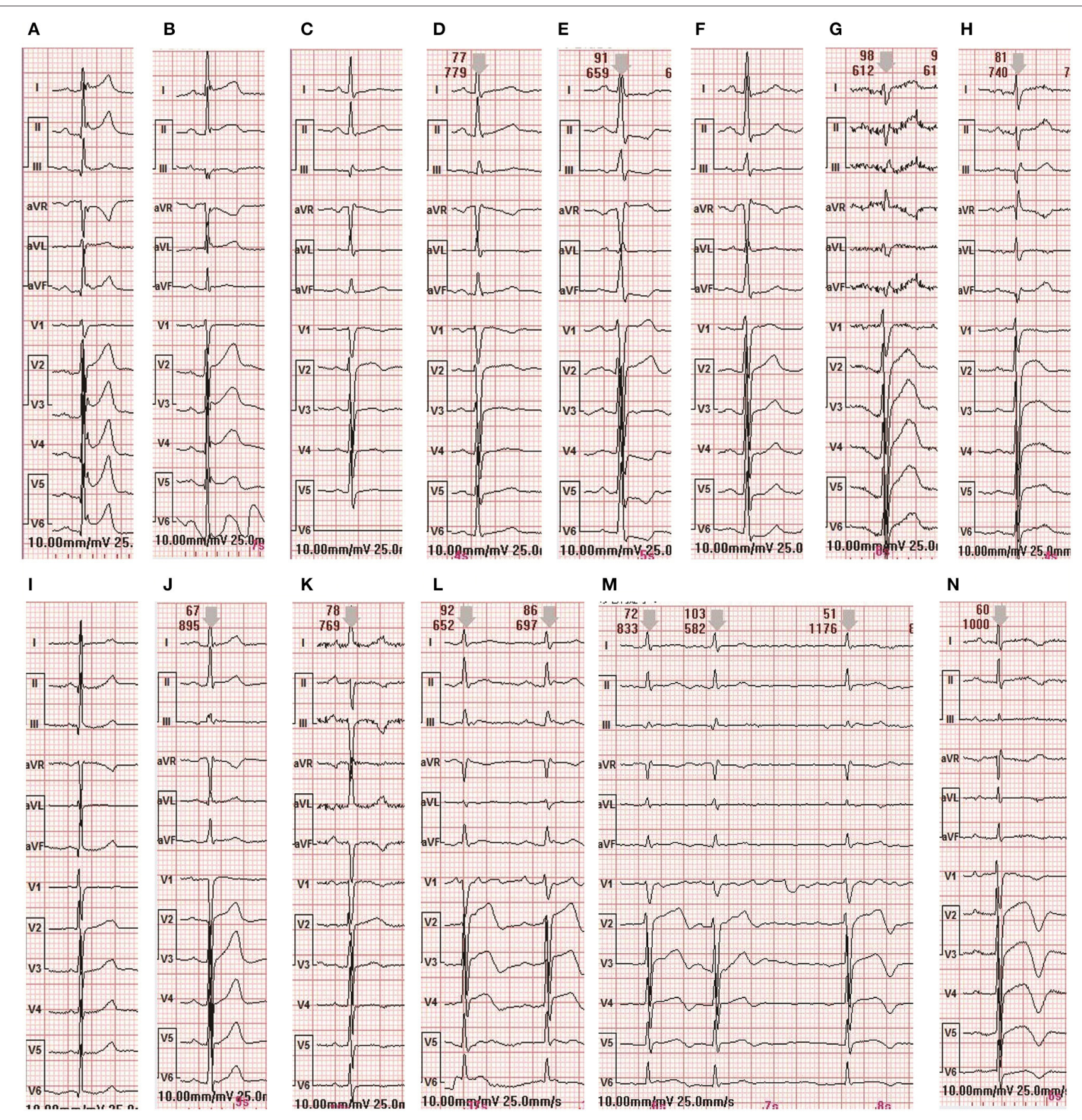

FIGURE 5 | ECG changes in 8 patients during hospitalization (A,B) are the ECG of admission and discharge of case 1 (C,D) are the ECG of admission and discharge of case $2(\mathbf{E}, \mathbf{F})$ are the ECG of admission and discharge of case $3 \mathbf{( G , H )}$ are the ECG of admission and discharge of case 4 (I) is the ECG of admission and discharge of case $5 \mathbf{( J )}$ is the ECG of admission and discharge of case $6 \mathbf{( K , L )}$ are the ECG of admission and discharge of case 8 (M-O) are the ECG of admission and discharge of case 9 .

dysfunction. A study by Fazio et al. (27) found slow coronary blood flow in 23 patients by evaluating TIMI frame count in 24 TTS patients. Finally, transient thrombosis in the anterior descending branch caused myocardial infarction. Ibanez et al. (28) conducted intravascular ultrasound examinations on 5 TTS patients and found that atherosclerotic plaque rupture in the anterior descending branch resulted in thrombosis. However, among the TTS patients we collected, there were 2 cases with slow coronary blood flow, and none of the patients showed obvious signs of coronary artery stenosis, which was consistent with the manifestations of TTS. The specific pathogenesis of TTS still needs further study. 
A

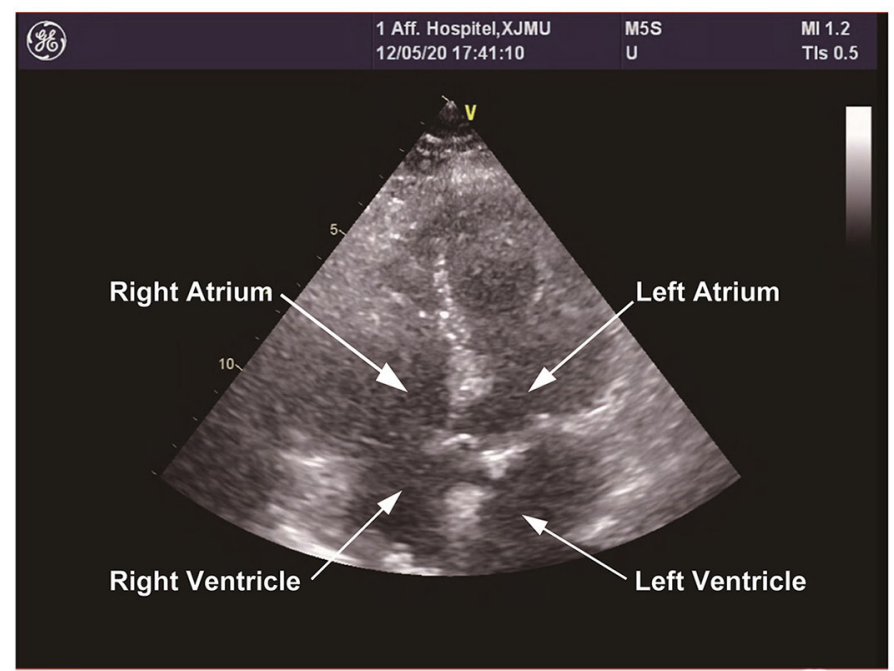

D

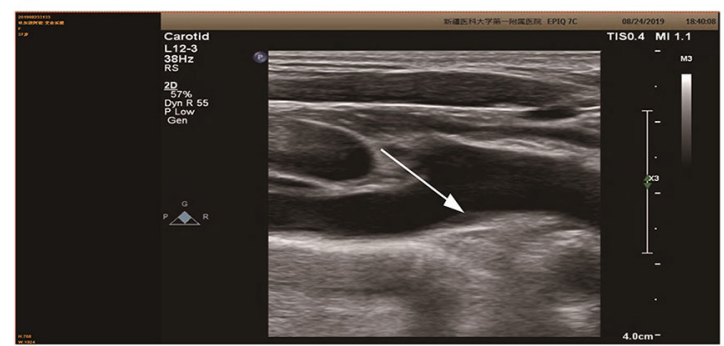

F

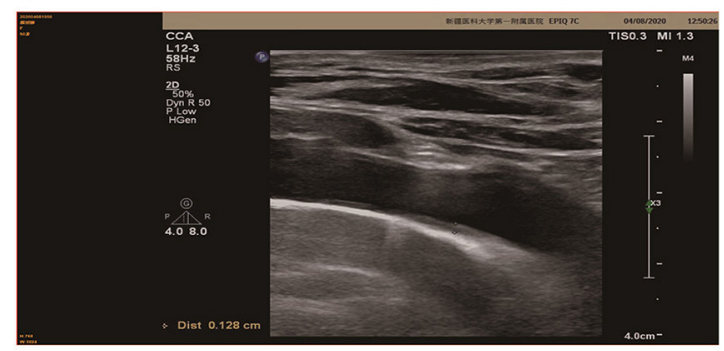

B

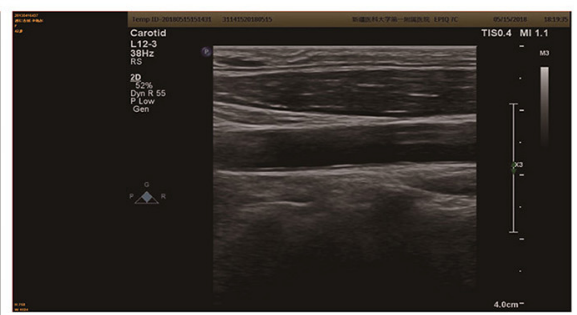

C

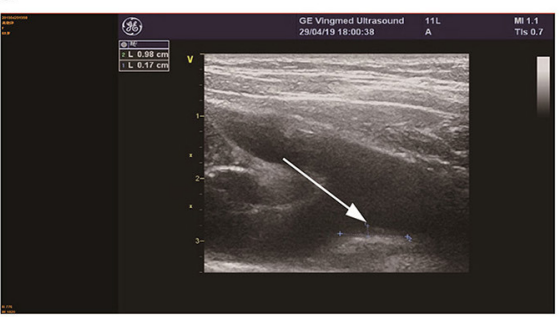

E

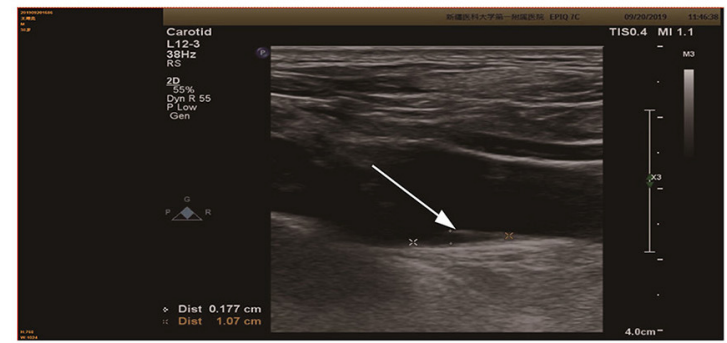

G

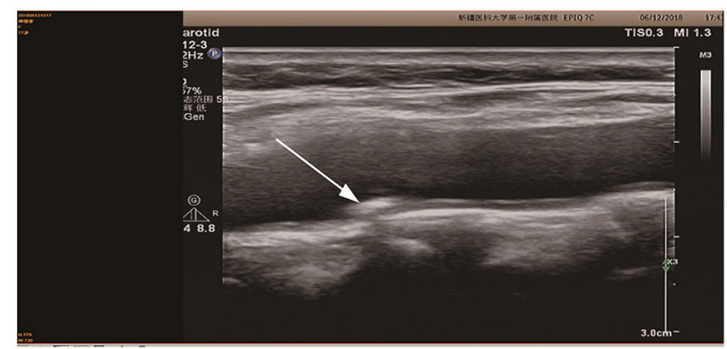

FIGURE 6 | Color Doppler ultrasonography of the neck and heart was performed in 6 patients. (A) The heart color Doppler ultrasound image of patient 9, and the results suggested left atrial enlargement, reduced left ventricular myocardial phase motion, mitral valve insufficiency, active surface insufficiency, and mild pulmonary hypertension. (B) is the cervical vascular color Doppler ultrasound of patient 3, there were no obvious abnormalities in cervical vascular ultrasound. (C) is the cervical vascular color Doppler ultrasound of patient 4 , and the results suggested that the innameless artery bifurcation and the plaque size of the right subclavian artery was about $9.8 \times 1.7 \mathrm{~mm}$, which has been marked in the figure. (D) is the cervical vascular color Doppler ultrasound of patient 5, and the results suggested that the innameless artery bifurcation and the plaque size of the right subclavian artery was about $10 \times 1.8 \mathrm{~mm}$, which has been marked in the figure. (E) is the cervical vascular color Doppler ultrasound of patient 6 , and the results suggested that the innameless artery bifurcation and the plaque size of the right subclavian artery was about $11.1 \times 1.8 \mathrm{~mm}$, which has been marked in the figure. $(\mathbf{F})$ is the cervical vascular color Doppler ultrasound of patient 8 , intima thickening of the left carotid artery $(1.2 \mathrm{~mm})$, bifurcation of the innominate artery and thickening of the right subclavian artery $(1.3 \mathrm{~mm})$, which has been marked in the figure (G) is the cervical vascular color Doppler ultrasound of patient 9, there were no obvious abnormalities in cervical vascular ultrasound.

After admission, we performed serological and related auxiliary examinations on TTS patients, and paired T-tests were performed on routine blood, biochemical, myocardial markers, and inflammatory indicators before and after admission. Only the counts of white blood cells and neutrophils were statistically significant. Morel et al. (29) studied 17 patients with TTS and found that the CRP of TTS patients was significantly elevated at admission, which was correlated with the LVEF and BNP.
An endocardial biopsy of TTS patients found that the reversible infiltration of inflammatory cells may be related to sympathetic nerve excitation, and cytokines and reactive oxygen species released by activated inflammatory cells may lead to myocardial injury, thereby causing an increase in inflammatory cells and myocardial markers. Furthermore, the improvement of heart color Doppler ultrasound examination revealed that TTS patients had different degrees of reduced left ventricular ejection fraction 
and abnormal ventricular wall motion, and typical patients could also have spherical apex dilatation. After follow-up, most patients had recovered their LVEF and ventricular wall motion. In a case-control study of 1,750 patients with TTS and ACS, it was found that TTS had a significantly lower left ventricular ejection fraction (22). Citro et al. (30) found that patients in the LVEF $\leq 35$ group were older than those in the LVEF $>35$ group and were more likely to have adverse cardiovascular events. Abumayyaleh et al. (31) found that after 5 years of follow-up, the long-term mortality of TTS patients was significantly higher than that of ACS patients. In a study of abnormal left ventricular wall motion and coronary artery flow, it was found that during the acute phase of TTS, the myocardial blood flow of the dysfunctional left ventricular segment was lower than that of the normal ventricular wall motion $(32,33)$. In summary, the study found that the main manifestation of TTS cardiac ultrasound is a disease with a good prognosis and a reduced LVEF. However, if the patient is an elderly female with multiple underlying diseases with an ejection fraction of $\leq 35 \%$, the patient likely has a poor prognosis. In addition, we also found plaque formation in the bifurcation of the innamental artery and the right subclavian artery in 5 patients with complete cervical artery color Doppler ultrasound. Currently, there is no relevant study on carotid artery plaque and TTS, and the mechanism is not yet clear.

In addition, the ECG of TTS patients showed the same ECG manifestations as ACS, such as ST segment elevation, ST segment depression and $\mathrm{T}$ wave inversion, accompanied by varying degrees of QT interval prolongation. Some studies believe that the prolonged QT interval may be due to the abnormal expansion of the left ventricular myocardium caused by the increased secretion of catecholamine and the temporary abnormal repolarization and dispersion caused by myocardial edema at the apex and base of the left ventricle. However, after $105 \pm 32$ days of TTS follow-up by Kurisu et al. (34), all ECG indicators of the patient basically returned to normal. An observational study of TTS by Madias et al. (35) found that corrected QT interval prolongation was associated with the occurrence of ventricular arrhythmias. Although ECG is normal in a few TTS patients, most TTS patients present with ACS-like ECG abnormalities on admission. Frangieh et al. (36) developed a standard to distinguish TTS from AMI, regardless of the presence of ST-elevation or non-ST-elevation myocardial infarction. Patients with TTS showed related ECG changes, and after follow-up, the ECG of all TTS patients returned to normal.

Three patients with TTS were hospitalized for single photon emission computed tomography scans (SPECT), and the results showed that 1 case with left ventricular wall motion was abated, and was accompanied by a significantly lower ejection fraction. There were different degrees of blood flow deficiencies in the left ventricle and apex. Some foreign studies have found that TTS patients may have abnormal perfusion or low and normal coronary blood flow reserve (37-39). Yoshida and Camici's study $(40,41)$ found that TTS reversibly decreased coronary blood flow reserve, but this was not associated with vascular structure changes. Combined with domestic and foreign studies, we found that TTS patients may have abnormal coronary blood perfusion, which may be caused by vascular spasm causing abnormal coronary blood perfusion, resulting in patients with various chest pain, breathing difficulties and other symptoms.

TTS is a group of clinical syndromes induced by mental or physical stimulation, with chest pain as the main symptom, partly accompanied by an increase in white blood cells, neutrophils, creatine kinase, troponin, prolonged QTC interval, and no obvious coronary stenosis. The prognosis is generally good, with few serious complications. In clinical practice, since the symptoms of this disease are similar to those of acute coronary syndrome, careful attention should be given to improving the diagnostic efficiency of TTS to reduce the symptoms.

\section{Limitations}

The limitations of this study were that the sample size was small, the average follow-up time was short, and typical left ventricular angiography images of patients with Takotsubo syndrome were not obtained due to posture or technical problems at that time, or because the possibility of this disease was not considered at that time. The next step of our research plan is to strengthen the research on the pathophysiological and other potential mechanisms of Takotsubo syndrome as well as the research on hematological biomarkers, and focuses on establishing a multicenter, large-sample, long-follow-up case study bank.

\section{DATA AVAILABILITY STATEMENT}

The raw data supporting the conclusions of this article will be made available by the authors, without undue reservation.

\section{ETHICS STATEMENT}

Ethical review and approval was not required for the study on human participants in accordance with the local legislation and institutional requirements. The patients/participants provided their written informed consent to participate in this study. Written informed consent was obtained from the individual(s) for the publication of any potentially identifiable images or data included in this article.

\section{AUTHOR CONTRIBUTIONS}

YM and XX supervised the project and designed the study. JY was responsible for analyzing and interpreting the data and wrote the manuscript. CD and QY were responsible for collecting, collating, and statistical data. SC and MM participated in part of revising work. All authors have read and approved the manuscript.

\section{FUNDING}

This research was funded by the National Natural Science Foundation of China (91957208, 81770235, and 81960046), State Key Laboratory of Pathogenesis, Prevention and Treatment of High Incidence Diseases in Central Asia Fund (SKL-HIDCA2019-4), and Prevention and control of major chronic Noncommunicable disease Project (2018YFC1311505). 


\section{REFERENCES}

1. Prasad A, Lerman A, Rihal CS. Apical ballooning syndrome (Tako-Tsubo or stress cardiomyopathy): a mimic of acute myocardial infarction. Am Heart J. (2008) 155:408-17. doi: 10.1016/j.ahj.2007.11.008

2. Tan WL, Luo Y. Clinical features of 5 cases of Tako-Tsubo cardiomyopathy. Guangzhou Med J. (2011) 42:5-8. doi: 10.3969/j.issn.1000-8535.2011.06.003

3. Mo JP. Diagnosis and treatment of 27 cases of stress cardiomyopathy. Nat Med Front China. (2013) 8:17. doi: 10.7748/ns2013.02.27.25.17.s7

4. Sun Q, Xuan J. Clinical analysis of Tako-Tsubo cardiomyopathy. Psychol Monthly. (2019) 21:25-6. doi: 10.19738/j.cnki.psy.2019.21.015

5. Gao Y, Wang XL, Du LP. Clinical analysis and summary of TakoTsubo syndrome. Inn Mong J Tradit Chin Med. (2010) 29:121. doi: 10.16040/j.cnki.cn15-1101.2010.22.145

6. Liu J, Lai J, He YC, Zhang XX. Clinical characteristics and prognosis of Takotsubo syndrome resembling acute myocardial infarction. J Sun Yat-Sen Univ. 41:627-34. doi: 10.13471/j.cnki.j.sun.yatsen.univ(med.sci). 2020.0082

7. Yang J, Li JJ, Hu XM, Hang Y, Yi W. Misdiagnosis of stress cardiomyopathy mimicking acute myocardial infarction in 20 cases. Clin Misdiagnosis Mistherapy. (2016) 29:22-5. doi: 10.3969/j.issn.1002-3429.2016.10.007

8. Wang YB, Sun M, Ren HC, Li ZW, Huang Y. Intracranial aneurysmal subarachnoid hemorrhage complicated by Takotsubo cardiomyopathy. Chin J Contemp Neurol Neurosurg. (2016) 16:360-5. doi: 10.3969/j.issn.1672-6731.2016.06.010

9. Yi B, Ye JF. Diagnosis and treatment of 8 cases of stress cardiomyopathy. Zhejiang Pract Med. (2011) 16:15-7. doi: 10.16794/j.cnki.cn331207/r.2011.01.007

10. Gan SJ, Zhang HB. Clinical analysis of stress myocardial cases. Chin J Diffic Comp Cas. (2013) 12:189-90. doi: 10.3969/j.issn.1671-6450.2013. 03.009

11. Le XD, Yang, WH, Lin YC. Misdiagnosis of stress cardiomyopathy in 15 cases. J North Pharm. (2012) 9:108-9. Available online at: https://kns.cnki.net/kcms/detail/detail.aspx?dbcode=CJFD\&dbname=CJF D2012\&filename $=$ BFYX201204101\&uniplatform $=$ NZKPT\&v $=$ roVYt $\% 25 \mathrm{~mm}$ d2Bu1PKDJ9ozbWQNrxDRoba51\%25mmd2Bz1x36LKwtUqEC1RTRsS8oGr mmEkhfAH8cRP

12. Hou LL. Analysis of clinical characteristics of stress cardiomyopathy. Zhejiang Med J. (2019) 41:2013-16. doi: 10.12056/j.issn.10062785.2019.41.19.2019-386

13. $\mathrm{Hu} \mathrm{YM}, \mathrm{Hu} \mathrm{YL}$, Yao L, Liu YG. Clinical characteristics of stress cardiomyopathy. Hebei Med J. (2010) 32:2512-3. Available online at: https://kns.cnki.net/kcms/detail/detail.aspx?dbcode=CJFD \&dbname $=$ CJFD2010\&filename $=$ HBYZ201018024\&uniplatform $=$ NZKPT\&v =IibvO4C95ZP6Yo5alBxJWk8KpG\%25mmd2BIFWEL1qZArK94aZ2SrnOD OJIpQ6KpMO6xqYCw

14. Jiang $\mathrm{MH}$, Ning $\mathrm{BH}$. Characteristic analysis of stress cardiomyopathy. Med Equip. (2016) 29:30-1. Available online at: https://kns.cnki.net/kcms/detail/detail.aspx?dbcode=CJFD\&dbname=CJFDL AST2016\&filename $=$ YLZB201612022\&uniplatform $=$ NZKPT\&v=XLb8uwkV udabui5eXIkGBcyTvYUaPSX6KmYwHvwCqGsHwApP86D4RQWeMZ3o PVlF

15. Li S. Analysis of clinical diagnosis and treatment of stress cardiomyopathy. J Navy Med. (2019) 40:555-7. doi: 10.3969/j.issn.1009-0754.2019. 06.018

16. Han GZ, Ma RP, Zhao FY. Analysis of 16 cases of stress cardiomyopathy misdiagnosed as acute myocardial infarction. Chin J Misdiagn. (2011) 11:1647. Available online at: https://kns.cnki.net/kcms/ detail/detail.aspx ?dbcode $=$ CJFD\&dbname $=$ CJFD2011\&filename $=$ ZWZX2011 07126\&uniplatform =NZKPT\&v=jQ9JfHdmYryhIxxhWHOYfdLzQ31doUs C1Zgxl5LiAZNfL5zpPwsRqjoozCfq0iyx

17. Lu HT, Li X, Zhou YH. Clinical analysis of stress cardiomyopathy misdiagnosed as acute myocardial infarction. J Yangtze Univ. (2013) 10:5-6. doi: 10.16772/j.cnki.1673-1409.2013.03.004

18. Feng JS, Zhang ZK, Ma JL. A meta-analysis of Tako-Tsubo cardiomyopathy in China. Chin J Gerontol. (2013) 33:3050-1. doi: 10.3969/j.issn.1005-9202.2013.13.020
19. Li JD, Guo M, Liu LX. Clinical analysis of subarachnoid hemorrhage complicated with stress cardiomyopathy. J Clin Emerg. (2016) 17:866-9. doi: 10.13201/j.issn.1009-5918.2016.11.014

20. Dote K, Sato H, Tateishi H, Uchida T, Ishihara M. [Myocardial stunning due to simultaneous multivessel coronary spasms: a review of 5 cases]. J Cardiol. (1991) 21:203-14.

21. Murugiah K, Wang Y, Desai NR, Spatz ES, Nuti SV, Dreyer RP, et al. Trends in short- and long-term outcomes for Takotsubo cardiomyopathy among medicare fee-for-service beneficiaries, 2007 to 2012. JACC Heart Fail. (2016) 4:197-205. doi: 10.1016/j.jchf.2015.09.013

22. Templin C, Ghadri JR, Diekmann J, Napp LC, Bataiosu DR, Jaguszewski M, et al. Clinical features and outcomes of Takotsubo (stress) cardiomyopathy. $N$ Engl J Med. (2015) 373:929-38. doi: 10.1056/NEJMoa1406761

23. Sharkey SW, Windenburg DC, Lesser JR, Maron MS, Hauser RG, Lesser JN, et al. Natural history and expansive clinical profile of stress (Tako-Tsubo) cardiomyopathy. J Am Coll Cardiol. (2010) 55:333-41. doi: 10.1016/j.jacc.2009.08.057

24. Lyon AR, Bossone E, Schneider B, Sechtem U, Citro R, Underwood SR, et al. Current state of knowledge on Takotsubo syndrome: a position statement from the taskforce on Takotsubo syndrome of the heart failure association of the European society of cardiology. Eur J Heart Fail. (2016) 18:8-27. doi: 10.1002/ejhf.424

25. Ueyama T, Hano T, Kasamatsu K, Yamamoto K, Tsuruo Y, Nishio I. Estrogen attenuates the emotional stress-induced cardiac responses in the animal model of Tako-Tsubo (Ampulla) cardiomyopathy. J Cardiovasc Pharmacol. (2003) 42(Suppl. 1):S117-9. doi: 10.1097/00005344-200312001-00024

26. Wittstein IS, Thiemann DR, Lima JA, Baughman KL, Schulman SP, Gerstenblith G, et al. Neurohumoral features of myocardial stunning due to sudden emotional stress. $N$ Engl J Med. (2005) 352:539-48. doi: 10.1056/NEJMoa043046

27. Fazio G, Sarullo FM, Novo G, Evola S, Lunetta M, Barbaro G, et al. Tako-Tsubo cardiomyopathy and microcirculation. J Clin Monit Comput. (2010) 24:101-5. doi: 10.1007/s10877-009-9217-5

28. Ibanez B, Navarro F, Cordoba MP, M-Alberca P, Farre J. Tako-Tsubo transient left ventricular apical ballooning: is intravascular ultrasound the key to resolve the enigma? Heart. (2005) 91:102-4. doi: 10.1136/hrt.2004. 035709

29. Morel O, Sauer F, Imperiale A, Cimarelli S, Blondet C, Jesel L, et al. Importance of inflammation and neurohumoral activation in Takotsubo cardiomyopathy. J Card Fail. (2009) 15:206-13. doi: 10.1016/j.cardfail.2008. 10.031

30. Citro R, Radano I, Parodi G, Di Vece D, Zito C, Novo G. Long-term outcome in patients with Takotsubo syndrome presenting with severely reduced left ventricular ejection fraction. Eur J Heart Fail. (2019) 21:781-9. doi: 10.1002/ejhf.1373

31. Abumayyaleh M, El-Battrawy I, Kummer M, Gietzen T, Behnes M, Zhou XB, et al. Association between mortality and left ventricular ejection fraction in patients with Takotsubo syndrome versus acute coronary syndrome. In Vivo. (2020) 34:3639-48. doi: 10.21873/invivo.12210

32. Vitale C, Rosano GM, Kaski JC. Role of coronary microvascular dysfunction in Takotsubo cardiomyopathy. Circ J. (2016) 80:299-305. doi: 10.1253/circj.CJ-15-1364

33. Abdelmoneim SS, Mankad SV, Bernier M, Dhoble A, Hagen ME, Ness SA, et al. Microvascular function in Takotsubo cardiomyopathy with contrast echocardiography: prospective evaluation and review of literature. J Am Soc Echocardiogr. (2009) 22:1249-55. doi: 10.1016/j.echo.2009.07.012

34. Kurisu S, Inoue I, Kawagoe T, Ishihara M, Shimatani Y, Nakamura $\mathrm{S}$, et al. Time course of electrocardiographic changes in patients with Tako-Tsubo syndrome: comparison with acute myocardial infarction with minimal enzymatic release. Circ J. (2004) 68:77-81. doi: 10.1253/circ j.68.77

35. Madias C, Fitzgibbons TP, Alsheikh-Ali AA, Bouchard JL, Kalsmith B, Garlitski AC, et al. Acquired long QT syndrome from stress cardiomyopathy is associated with ventricular arrhythmias and torsades de pointes. Heart Rhythm. (2011) 8:555-61. doi: 10.1016/j.hrthm.2010.12.012

36. Frangieh AH, Obeid S, Ghadri JR, Imori Y, D'Ascenzo F, Kovac $\mathrm{M}$, et al. ECG criteria to differentiate between Takotsubo (Stress) 
cardiomyopathy and myocardial infarction. J Am Heart Assoc. (2016) 5:e003418. doi: 10.1161/JAHA.116.003418

37. Kobylecka M, Budnik M, Kochanowski J, Piatkowski R, Chojnowski $\mathrm{M}$, Fronczewska-Wieniawska $\mathrm{K}$, et al. Takotsubo cardiomyopathy: FDG myocardial uptake pattern in fasting patients comparison of PET/CT, SPECT, and ECHO results. J Nucl Cardiol. (2018) 25:1260-70. doi: 10.1007/s12350-016-0775-x

38. Sadamatsu K, Tashiro H, Maehira N, Yamamoto K. Coronary microvascular abnormality in the reversible systolic dysfunction observed after noncardiac disease. Jpn Circ J. (2000) 64:789-92. doi: 10.1253/jcj.64.789

39. Ako J, Takenaka K, Uno K, Nakamura F, Shoji T, Iijima K, et al. Reversible left ventricular systolic dysfunction-reversibility of coronary microvascular abnormality. Jpn Heart J. (2001) 42:355-63. doi: 10.1536/jhj.42.355

40. Yoshida T. Hibino $\mathrm{T}$, Kako $\mathrm{N}$, Murai $\mathrm{S}$, Oguri $\mathrm{M}$, Kato $\mathrm{K}$, et al. A pathophysiologic study of Tako-Tsubo cardiomyopathy with F-18 fluorodeoxyglucose positron emission tomography. Eur Heart J. (2007) 28:2598-604. doi: 10.1093/eurheartj/ehm401

41. Camici PG, Crea F. Coronary microvascular dysfunction. N Engl J Med. (2007) 356:830-40. doi: 10.1056/NEJMra061889
Conflict of Interest: The authors declare that the research was conducted in the absence of any commercial or financial relationships that could be construed as a potential conflict of interest.

Publisher's Note: All claims expressed in this article are solely those of the authors and do not necessarily represent those of their affiliated organizations, or those of the publisher, the editors and the reviewers. Any product that may be evaluated in this article, or claim that may be made by its manufacturer, is not guaranteed or endorsed by the publisher.

Copyright (c) 2021 Yan, Madina, Deng, Yuan, Cao, Xie and Ma. This is an open-access article distributed under the terms of the Creative Commons Attribution License (CC BY). The use, distribution or reproduction in other forums is permitted, provided the original author $(s)$ and the copyright owner(s) are credited and that the original publication in this journal is cited, in accordance with accepted academic practice. No use, distribution or reproduction is permitted which does not comply with these terms. 